\title{
The Path Choice of Transformation and Upgrading of Manufacturing Industry in China Based on Supply- side Structural Reform
}

\author{
Shuang Qiu \\ China West Normal University \\ Nanchong, China
}

\begin{abstract}
Manufacturing is not only the main body of the real economy but also the backbone of the economy to maintain high growth and industry towards to the mediumhigh-level. At present, China has become the world's manufacturing large country, and the status of international trade has been rising. However, there are still many problems in China's manufacturing industry, especially the structural problems. China is far from being the world's manufacturing power. The strategy of supply-side structural reform provides new opportunities for the transformation and upgrading of manufacturing industry.
\end{abstract}

Keywords-manufacturing industry; transformation and upgrading; supply-side structural reform

\section{INTRODUCTION}

Manufacturing industry is an important part of national economy, and it is a direct embodiment of the level of national productivity. Through30 years of rapid development, China has become the largest manufacturing country in the world. In China, Manufacturing output has accounted for $20 \%$ of the global share, more than 220 kinds of industrial output ranked first in the world, manufacturing net exports has been NO.1 in the world. However, due to the lack of independent innovation ability, coupled with the traditional mode of development and management, our country is still weak in key technologies and key components of "core, high-end, basic". The problem of "big but not strong" is outstanding in manufacturing industry, and the sustainable development has been hindered seriously. China's manufacturing industry is still at the mid-low end of global industry and value chain. In order to promote develop healthy, elevate the value chain and the international competitiveness of products of China's manufacturing industries, we must look for a new path to achieve the transformation and upgrading. The proposed structure reform of supply-side provides new chances for the transformation and upgrading of manufacturing industry.

Fund project: National social science fund project in general (13BJL010); Scientific research innovation team in China West Normal University (CXTD2013-9); Meritocrat fund projects in China West Normal University (17YC304)

\section{ChInA's ManUfacturing IndUSTRY FACES SEVERE STRUCTURAL CONSTRAINTS}

\section{A. At the Low and Middle-end of Globalindustry Chain and Value Chain}

At present, the overall level of China's manufacturing industry is still at the middle and low level of the global manufacturing value chain.70\% of the manufacturing industry is traditional processing manufacturing, which is engaged in assembly processing and the added value of product is relatively lower. For a long time, China's manufacturing industry has emphasized on hardware and scale expansion while despised software and technological innovation, which results in China is a big manufacturing country rather than a brand leading powers. The majority of manufacturing enterprises which have universal homogeneity, low-level duplication of construction and can't satisfy market differential demand are very weak in innovation ability. They are constrained by foreign buyers, stranded in low value-added manufacturing. Ultimately they can't support the implementation of the strategy, such brand and marketing. Foreign manufacturers which often depend on the brand, marketing, research, services and other nonmanufacturing advantages occupy the high-end market, while China's manufacturing industry is mostly in the lowend, and they become foreign enterprises "wage earners".

\section{B. Overcapacity and Mismatch of Supply and Demand}

In the field of manufacturing industry, there are some problems such as overcapacity, heavy cost burden, low production efficiency and low benefit. At the same time, there is a mismatch between supply and demand, and the supply quality and efficiency are not high, which seriously affect the overall development level of China's industrial economy. On the one hand, major industries such as steel, coal, cement, glass, petroleum, petrochemical, ironore, nonferrous Metals, overcapacity is serious, and the scale of losses have reached $80 \%$.It's worth noting that some of the strategic emerging industries, including photovoltaic, wind power and new materials (carbon fiber) is faced similar situation. On the other hand, the structural dislocation of the supply system caused supply the bad substantially, not to satisfy the growing diversity, multi-level, fast-paced social 
demand, resulting in a significant slowdown in domestic consumption demand, residents are crazy about shopping overseas, investment growth rate has dropped significantly; domestic air passenger transport growth slowdown, but Cross-border travel continues to grow high. In 2015, Chinese tourists spend 11205 yuan per capita on overseas tourism, $21 \%$ increase year-on-year. Chinese have become the most purchasing power group for three consecutive years. In 2015, China's imports of High-tech products amounted to $\$ 548.06$ billion, which continued to rise. Domestic residents of overseas consumption increase year by year. For example, the overseas parcel post to Nanjing customs in 2015 reached 1.34 million pieces, up $185 \%$ from 2014. Advanced high-end products are still dependent on imports, and the domestic market is in short supply.

\section{Factor Utilization is Inefficient}

The development of China's manufacturing industry presents the characteristics of "Three High and One Low", that is, high input, high consumption, high pollution and low efficiency. Due to the excessive reliance on land, resources, labor and other general production elements of investment, there is relatively few high-end economy of the industry, resource consumption serious, and enterprises difficult to profit. Meanwhile, there are lots of zombie enterprises in manufacturing, which greatly reduces the supply quality of the market, and restricts the improvement of the overall technical level and factor use efficiency. Therefore, it is urgent to redistribute the elements and capital so as to stimulate the market vitality.

\section{Traditional Development of Kinetic Energy is Unsustainable}

China's manufacturing industry is mainly labor-intensive and resource intensive, and it is a typical extensive development model. In Our country, this mode of development is more suitable for the early stage of reform because of rich labor resources, the manufacturing industry starting late and weak foundation. However, with the development of economy, this mode is difficult to sustainable development, to obtain the optimization and upgrade of sustainable development and trade due to the disappearance of the demographic dividend, the rising price of labor, land and raw material, the increase of enterprise's production cost.

At present, the motive force of development driven by innovation has not yet formed, and the biggest weakness off manufacturing is the absence of capacity for independent innovation. In 2015, China's high-tech industry output accounted for only $11.8 \%$, and emerging industries accounted for less than $10 \%$ of GDP. The situation is no fundamental change that some key technologies is controlled by other peoples: the import rate of domestic high-end CNC products reaches $80 \%$; some large-scale construction machinery, high-grade $\mathrm{CNC}$ machine tools and other imported key components accounted for more than $40 \%$ of the cost of the whole machine; electronic information manufacturing equipment imported from abroad mainly. The gap in technology of "made in China" is still great.

\section{THE IMMANENT RELATIONS OF SUPPLY-SIDE STRUCTURAL REFORM AND THE TRANSFORMATION OF MANUFACTURING INDUSTRY}

The so-called "supply-side structural reform" means starting with the supply and production sectors, promoting structural adjustment through reform, reducing ineffective and low-end supply, expanding effective and middle-to-highend supply, to raise the total factor productivity and to make the supply system adapt the changes in demand structure better. This is a major strategic plan that the Central Committee with Comrade Xi Jinping as the core focuses on the overall situation of China's economic development and is adapting to and leading the new normal of economic development. It is also a new device and working part of maintaining the rapid development of China's economy and pushing forward the industrial structure towards the middle and high-end.

\section{A. The Key to Supply-side Structural Reform Lies in the Optimization and Upgrading of the Manufacturing Structure}

Manufacturing is the main battlefield for supply-side structural reforms. On the whole, the major contradictions in the domestic supply system are the mismatch, inharmonious and imbalance between products supply and market demand, and the highlight is that supply can't adjust in good time when adapting to the great changes of demand and the structural overcapacity is serious. The supply-side structural reform proposed by the Party Central is mainly focuses on the issue of mismatch between supply and demand and focuses on improving total factor productivity. It pays attention to seeking breakthroughs in three major aspects: institutional reform, structural optimization and factor upgrading. The structural optimization from the supply side is implemented to increase Effective supply of macro-control in the long-term development. This requires that China's manufacturing industry must focus on improving quality and efficiency, take the supply-side structural reform as the principal line, promote the effective connection between supply and demand, promote industrial upgrading and demand upgrading, promote total factor productivity and increase the sustained economic growth momentum.

\section{B. Transformation and Upgrading of Manufacturing Needs to be Achieved through Structural Reform of the Supply Side Structural Reform}

The supply-side structural reform is with a view to the five tasks of "removing capacity, removing inventory, deleveraging, lowering costs and making up for shortcomings", which emphasizing structural adjustment. It promotes the utilization efficiency of total factor productivity and enhances the adaptability and initiative of market players through the structural adjustment of the whole production system. The completion of the five major tasks can have the following positive impact on the domestic manufacturing industry.

Firstly, business costs can be declined, market competitiveness can be improved. Especially in the aspect of 
human resource costs, along with the reform of national social security, pension system and the interest rate liberalization, the cost of undertaking taxes and fees will be reduced and the market competitiveness will be enhanced.

Secondly, the proportion of low-end manufacturing declined while the proportion of high-end manufacturing increased. A precise focus of supply-side structural reform is to solve the problem of insufficient supply of high-end products and industries, and to promote the continuous optimization and upgrading of the industrial structure.

Thirdly, the share of manufacturing industry will drop while the proportion of modern service industry, especially that of producer services will rise. The development of modern producer services such as R \& D and design, modern logistics, financial business, service outsourcing and aftersales service will greatly exceed the manufacturing industry itself. Service-oriented manufacturing industry has become an important direction for the development of transformation.

Fourthly, business development environment will improve continuously. In the supply-side structural reform, the government will make every effort to help enterprises reduce costs and optimize their production and business environment. Accelerate the reform of market-oriented resource-based products, focus on reducing the cost of production factors, improve the efficiency of resource allocation, and lay down a combination blow of reducing the cost of institutional transactions, labor, tax burden, social insurance, finance, production factors and logistics of enterprises. In the meantime, the government will further deepen the functional reforms, simplify its administration and decentralize power, do the top-level design, implement the policy of canceling administrative examination and approval, clean up administrative fees and other policies, effectively reduce the burden on enterprises and continuously improve the development environment.

\section{THE PATH OF MANUFACTURING TRANSFORMATION AND UPGRADING BASED ON SUPPLY-SIDE STRUCTURAL REFORM}

\section{A. Optimize the Supply Structure Vigorously and Promote the Development of the Industry towards Middle-to- high-end}

Through technology innovation, brand building, and transform it from labor-intensive to technology-intensive, knowledge- intensive type. Especially, we must attach importance to the cultivation and expansion of strategic emerging industries and give priority to fostering a group of strategic emerging industrial clusters with independent core technologies, strong growth and future direction. Information and network are the necessary supports to promote supplyside structural reforms. It is necessary to strengthen the construction of big data, promote the manufacturing service, promote digital manufacturing based on the Internet, develop new modes of network production such as personalized customization, crowd sourcing design and cloud manufacturing, and support the construction of industrial cloud and public service platforms for SMEs and promote $\mathrm{R}$
\& D design, Data management, engineering services and other resources open to share, build a network of enterprise clusters.

\section{B. Create New Market Supply Actively}

Firstly, develop new formats and new models. We should foster and support new technologies, new technologies and new business models with good prospects for development, large capacity and high efficiency, and guide and promote the traditional manufacturing industry to actively develop formats and model innovations, expand the space for industry and enterprise development, and foster new economic growth point.

Secondly, build "Internet +" sharing platform. To comply with the development trend of "Internet + " in the world, promote the in-depth integration with the Internet, build a "double hit" platform for large-scale Internet-based manufacturing enterprises and a third-party service platform for SMEs, actively cultivate network collaborative manufacturing and personalized customization, Serviceoriented manufacturing and other new forms of networked production, enhance the support for the development of the manufacturing industry and the Internet, consolidate the basis for the integration and development, and stimulate the development of new momentum in the manufacturing industry. At the same time, build a multi-level and multilevel functional public service platform such as industrial cloud and big data, promote the open sharing of manufacturing resources, improve the smooth flow of information and achieve effective docking between supply side and demand side.

Finally, develop shared economy. At present, the rapid development of the shared economy has become a "new road to economic growth". $1 \mathrm{We}$ will actively develop the sharing of the economy through crowd sourcing, wisdom, public support and crowd funding so as to provide more momentum for grafting supply and demand, promoting employment and economic growth. We will also establish a variety of Internet sharing platforms, improve the network information security system and provide economic development sharing Protection.

\section{Efforts to Fill the Short Board of Innovate, Do Better the Replacement of New and Old Kinetic Energy}

Emphasize the role of innovation and give full play to the leading role of science and technology innovation in overall innovation. Strengthen basic research, strengthen original innovation, integrate innovation and introduce, absorb and re-innovate, enhance the capability of independent innovation, and provide a lasting impetus to economic and social development. Emphasis on the role of enterprises as the mainstay of innovation, focusing on cultivating innovative leader, speed up innovation resources, innovation policies, innovative services to the business agglomeration. In the direction of demand orientation and industrialization, promote the deep integration of production, learning and

Li keqiang. Draw the new blueprint of the world economy ncrease[N] People's Daily, 2015-9-11. 
research, and promote the industrialization of major innovations.

Around the development of national strategic emerging industries, the "Made in China 2025" and the construction of science and technology innovation centers focus on key fields such as smart manufacturing, high-end software, smart and new energy vehicles, original new medicines and highend medical equipment, deepen the connection between industry and science and technology. Accelerate the organization and implementation of a number of major scientific and technological achievements, transformation and demonstration projects, optimize the promotion mechanism and policy support, as soon as possible to achieve mass production and demonstration applications.

\section{Emphasize Deepening the Reform of the System to Stimulate the Manufacturing Industry Vitality}

Further transform government functions and strengthen institutional supply, and take effective measures in improving the market environment, deepening the examination and approval system reform and the commercial system reform. Establish dynamic adjustment mechanism to clarify the boundaries of government functions and stimulate the market and the vitality of enterprises; Integrate existing policy tools and strengthen the coordination and coordination of policies and industrial policies on finance, taxation, finance, investment and pricing; Actively study the policy of diversion and distribution of workers and staffs, properly handle Labor relations and social security; Improve the tracking service mechanism for major projects; Improve the linkage system between key enterprises; Innovate the mechanism for interaction between government and enterprises; Continue to promote industrial reform and innovation, push out a series of pilots for reform and innovation; Push forward the reform of examination and approval system for technological transformation projects; Further simplify the examination and approval matters.

\section{CONCLUSION}

In short, the basic path to promoting supply-side structural reforms in manufacturing industries is working hard to eliminate inefficient supply, reducing low-end supply, expanding effective supply and creating new supply, speeding up relevant institutional mechanisms and policy innovations, and leading the supply-side structural reforms to a deeper level, then gradually improving the supply structure of the adaptability to the demand structure.

\section{REFERENCES}

[1] Shen Kunrong; Li Zhen. Transformation and Upgrading of China's Manufacturing Industry in the Context of Supply-side Structural Reform[J].Social Sciences in Chinese Higher Education Institutions, 2017(1): 65-73.

[2] Chen jinhui. Research on transformation and upgrading of manufacturing Based on the supply side reform[J].China Machinery \& Electric Industry, 2017(5): 94-97.

[3] Pang zijun.Research on Transformation and Upgrad of Manufacturing in China[D]. Tianjin normal university,2012.
[4] Sun bo. The transformation and upgrading of China's manufacturing industry[J]. China National Conditions and Strength, 2013(8):11-12.

[5] Zhang zhiyuan. the dynamic mechanism and strategic trend of Transformation and Upgrad of Manufacturing in China Under the new normal[J].Inquiry into Economic Issues, 2015(6): 145-147.

[6] Zhang zhiyuan. The dynamic mechanism and strategic trend of Transformation and Upgrad of Manufacturing in China Under the new normal[J].Inquiry into Economic Issues, 2015(6): 145-147. 